
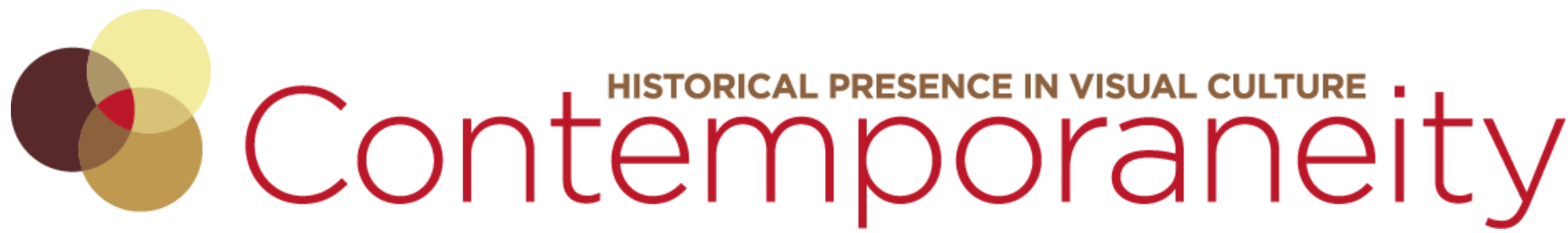

Vol 3, No 1 (2014) | ISSN 2155-1162 (online) | DOI 10.5195/contemp.2014.57 http://contemporaneity.pitt.edu

\title{
Kinetic Systems Jack Burnham and Hans Haacke
}

Christina Chau

\section{Abstract}

The following paper argues that Jack Burnham's antipathy for kineticism in "Systems Esthetics" and Beyond Modern Sculpture has contributed to an assumption that kineticism is an obsolete practice "rooted in another age." Contrary to Burnham, I argue that a focus on the kinetic movement in Hans Haacke's sculptures is productive for establishing key understandings of systems theory in art. My interpretation of Haacke's art emphasizes that movement in time is a key aspect of the artist's approach to sytems theory, and is useful for making viewers conscious of the systems of perception at play when confronted with ontologically unstable works of art.

\section{About the Author}

Christina Chau is a lecturer at the University of Western Australia in the School of Social Sciences, and the Department of Architecture, Landscape and Visual Arts. Her Ph.D. thesis is titled "The Polemics of Contemporary Kinetic Art History: Duration, Systems Aesthetics and the Virtual." 
Kinetic Systems

\section{Jack Burnham and Hans Haacke}

This is a shift from being to becoming. Kinetic works reflect this shift since kinetic works refute static space. They destroy lineal time. Kinetic works do not occupy space, they create space. Kinetic works do not contain time, they create time. Kinetic works so not interpret reality, they are reality.

Willoughby Sharp ${ }^{1}$

There has been a longstanding view that kinetic art is an antiquated practice that has little relevance to contemporary society. Recent exhibitions such as Ghosts in the Museum at the New Museum in New York (2012) was publicized as "an unsystematic archive" that displayed a "cabinet of curiosities" made by artists of past technological ages. ${ }^{2}$ Here, the term "kinetic" is coded as a historical and formal experimentation with an industrial machine aesthetic in art, one that began as early as Naum Gabo's Kinetic Construction: Standing Wave and Laaszlo Moholy-Nagy's Light Space Modulator (1922-1930), and reached a climax in popularity in Europe and the United States in the $1960 \mathrm{~s}^{3}$ Kineticism is not, however, often nostalgically remembered as a trend "rooted in another age."

Consequently, this view has contributed to what Arnauld Pierre has described as a "flagrant dearth" of critical and historical engagement with kinetic art. ${ }^{5}$ One of the first art historians to consider kineticism as an outdated practice was Jack Burnham in Beyond Modern Sculpture: The Effects of Science and Technology on the Sculpture of this Century. Burnham argued that prior to 1968 kineticism had the potential to become a dominant artistic practice that intersected with science, art, and technology. ${ }^{6}$ According to Burnham, artists were ultimately "unrequited" in their aims because many of them did not reflect on

\footnotetext{
${ }^{1}$ Jack Burnham quoted in Willoughby Sharp, Air Art (New York: Kineticism Press, 1966), 4.

2 "Ghosts in the Museum," The New Museum, New York, accessed April 28, 2014, http://www.newmuseum.org/exhibitions/view/ghosts-in-the-machine. Similarly, the exhibition Force Fields, Phases of the Kinetic (2000) at the Museu d'Art Contemporani de Barcelona (MACBA) was publicized as an an opportunity to "reintroduce us to an investigation of movement in art which in the mid-twentieth century became obscured." See Mark Nash, "The Art of Movement," in Force Fields: Phases of the Kinetic (London: Hayward Gallery, 2000), 313.

${ }^{3}$ For historical analyses of Gabo and Moholy-Nagy as seminal artists for kinetic art history see Christina Chau, "Building New Perceptions of Duration through Laszlo Moholy-Nagy's Light Space Modulator," Journal of Arts Theory and History 7, no. 3 (2013): 19-25; Joyce Tsai, "The Sorcerer's Apprentice: László Moholy-Nagy and His Light Prop for an Electircal Stage," The Aesthetics of the Total Artwork: On Borders and Fragments, ed. Anke Finger and Danielle Follett (Baltimore: John Hopkins University Press, 2011); Frank Popper, Origins and Developments of Kinetic Art (New York: New York Graphic Society, 1968).

${ }^{4}$ Alan Riding, "Arts Abroad: Retro or Nostalgic, the Work Never Stops Moving," NewYork Times, August 16, 2000, accessed, April 28, 2014, http://www.nytimes.com/2000/08/16/arts/arts-abroad-retro-ornostalgic-the-work-never-stops-moving.html

${ }^{5}$ Arnauld Pierre, "Instability: The Visual/Bodily Perception of Space in Kinetic Environments," in The 'DoIt-Yourself' Artwork: Participation From Fluxus to New Media, ed. Anna Dezeuze (Manchester: Manchester University Press, 2010), 91.

${ }^{6}$ Jack Burnham, Beyond Modern Sculpture: The Effects of Science and Technology on the Sculpture of this Century (New York: George Braziller, 1968).
} 
the emerging technological aesthetic at the time and became marginalized by emerging artistic practices, theory, and criticism. ${ }^{7}$

Burnham's disregard for kineticism continued in two seminal essays published in Artforum: "Systems Esthetics" and "Real Time Systems. ${ }^{18}$ It is in the former that Burnham explicitly declares kineticism to be an antiquated modern art practice. This is partly performed by Burnham in the essay by deemphasizing the use of movement by Hans Haacke in his early systems art. While Burnham's argument uses systems theory to exclude the effect of movement from critical discourses, this paper argues that artists such as Hans Haacke-whose work Burnham depended on to demonstrate the operation of systems aesthetics in art-also emphasised the form, function and movement of his early sculptural systems. Contrary to Burnham's perspective, which defines kinetic sculpture solely according to the movement of mechanical form, Haacke approaches kinesis as an orchestration of movement that is used to heighten the awareness of viewers who are positioned to seek the perceptual edge from actual and virtual movement in real time as an accumulation and release of intensity. ${ }^{9}$

The popularity of Burnham's "Systems Esthetics" in art theory and history has strongly impacted on contemporary perspectives of kinetic art history, which is why his essay is a key focus in this paper. ${ }^{10}$ This paper will begin by unpacking the key understanding of Burnham's "Systems Esthetics" as an attempt to predict the future intersections between art, science, and technology as becoming increasingly based on systems and cybernetic theory. Secondly, the paper will highlight Burnham's exclusion of kineticism from "Systems Esthetics," "RealTime Systems," and Beyond Modern Sculpture, and argue that his position is dependent on works that use movement to explore conceptual and post-formalist objectives. Burnham's emphasis on automata, lumia, robotics and cybernetic art performs a reterritorialization that moves from kinetic movement towards the movement of system processes. ${ }^{11}$ This is most prominently addressed through Hans Haacke's early systems art that was made during the 1960s and 1970s, and whose works I address as dependent on actual movement to signify, perform and process biological, political and natural weather systems. Burnham's emphasis on the movement of systems art, rather than the movement of kinesis, is more than a syntactical argument. As I will argue, Burnham attempts to sequester the theory and practice of movement in art away from the postmodern aesthetics that were emerging at the time. The effects of Burnham's argument and the popularity of his views in contemporary scholarship has reified a regard for kinetic sculpture and installation as a modern mechanical

\footnotetext{
${ }^{7}$ Burnham, Beyond Modern Sculpture, 218-221.

8 Jack Burnham, "Systems Esthetics," Artforum 7 no. 1 (September 1968): 30-35 and "Real-Time Systems," Artforum 8, no. 1 (1969): 49-55. Although Burnham used the term "Esthetic" in his "Systems Esthetics," the term is more popularly used as "Systems Aesthetics" in contemporary discourse. Considering this, this paper will use "aesthetics" except for instances where Burnham's paper "Systems Esthetics" is used.

${ }^{9}$ Burnham, Beyond Modern Sculpture, 218-220.

${ }^{10}$ See to Caroline Jones, "System Symptoms," Artforum 51, no. 1 (2012): 113-114; Nicholas Luhmann, Art as a Social System (Stanford California: Stanford University Press, 2000); Edward Shanken, "Reprogramming Systems Esthetics: A Strategic Historiography" Digital Arts and Culture (2009) accessed April 11, 2013, http://escholarship.org/uc/item/6bv363d4; Francis Halsall, Systems of Art: Art, History and Systems Theory (Oxford: Peter Lang, 2008); David Joselit, American Art Since 1945 (London: Thames and Hudson, 2003); Charissa Terranova, "Systems and Automatisms: Jack Burnham, Stanley Cavell and the Evolution of a Neoliberal Aesthetic," Leonardo 47, no. 1 (2014): 56-62.

${ }^{11}$ Burnham, Beyond Modern Sculpture, 185-378.
} 
and antiquated practice in art, and is therefore a central influence on contemporary reflections on the histories of kineticism.

\section{Jack Burnham's "Systems Esthetics"}

During the 1960s, the term "systems" was utilised over a wide range of disciplines that called for an open theory of organisation and communication within scientific, biological and cultural analysis. Many of the systems discourses, analyses and aesthetics were influenced by Ludwig von Bertalanffy's General Systems Theory, which regarded biological processes of evolution and adaptation as a number of intersecting systems. ${ }^{12}$ Outside the sciences, systems theory was appropriated to negotiate the flows of information within technological media in communications, ${ }^{13}$ and it was useful as a model for understanding patterns and processes within economics, chemistry, biology, engineering, sociology, physics and art. ${ }^{14}$ Even though there were many interpretations and divergences from Bertalanffy's original theory, systems in general quickly became a rubric for understanding how modern society was organised. ${ }^{15}$ Sanford Kwinter has emphasised that this entailed a "shift in twentiethcentury thought toward a biological model."16

Fundamentally, a system can be thought of as a number of variables that have the capacity to relate to one another, and which form a larger, rationalized whole. ${ }^{17}$ What is unique about a system is not so much its actual components but the way they are organised. Unlike chaos, systems are defined by the relationships between variables, each of which contributes to the unique form of the entire system. Systems can be quite open-for instance, the entire world can be considered as a total system ${ }^{18}$-but there is a key set of criteria that defines them. A system must have one or more key identifiable functions, and each individual variable within the system must also genuinely contribute that system's function. ${ }^{19}$ If one component is removed from the system, its function is consequently altered from its previous state. From this basic criteria, systems can be organised to take a wide variety of structures, including pattern, rhythm, or network. ${ }^{20}$

${ }^{12}$ Ludwig von Bertalanffy, General Systems Theory: Foundations, Developments, Applications (New York: G Braziller, 1968/1969).

${ }^{13}$ A key influence for considering information theory as a system in communications theory is Claude Shannon in 1948 at Bell Laboratory. See a later expanded version: Claude Shannon and Warren Weaver, The Mathematical Theory of Communication (Chicago: University of Illinois Press, 1963 [1998]). Another key contributor that has influenced the theoretical discussion of systems is Norbert Wiener in his Cybernetics or Control and Communication in the Animal or Machine (Cambridge, MA: MIT Press, 1948).

${ }^{14}$ For an example of a systems approach to scientific theory see Gregory Bateson, Steps to an Ecology of Mind (New York: Ballantine, 1972).

${ }^{15}$ Francis Halsall, Systems of Art: Art, History and Systems Theory (Oxford: Peter Lang, 2008), 21-66.

${ }^{16}$ Sanford Kwinter, Architectures of Time: Toward a Theory of the Event in Modernist Culture (Cambridge, Massachusetts: The MIT Press, 2001), ix.

17 Halsall, Systems of Art, 22-34.

18 Ibid., 9.

19 Ibid., 23-24.

${ }^{20}$ Kenneth Boulding, The World as a Total System (Beverly Hills, California: Sage, 1985), 9. Although there are entropic systems, these systems depend on the regular rate or probability of chaos as a constant. Entropy, for instance, is a state of regular rate of chaos. 
Burnham's approach to systems theory was hinged on the interdisciplinary and applicability of Bertalanffy's general systems theory. ${ }^{21}$ If a system was defined as "a complex of components in interaction," 22 Burnham considered art as a system that intersected with all areas of life, from which new subsystems would emerge. As he explained, systems theory " is focused on the creation of stable, on-going relationships between organic and nonorganic systems, be these neighbourhoods, industrial complexes, farms, transportation systems, information centers, recreation centers, or any other matrixes of human activity. All living situations must be treated in the context of a systems hierarchy of values." ${ }^{23}$ Therefore, Burnham's use of systems theory was constructed as an open, porous and intersecting system that encompassed the behaviours, actions and tendencies within all artistic practices that relate to and affect society.

Influenced by Lucy Lippard's reflection on the dematerialised object in the 1960s, and Norbert Wiener's cybernetic theory, Burnham's argument depended on an anti-ontological focus on systems theory in art. ${ }^{24}$ As he described, "[t]he object denoted sculpture in its traditional physical form, whereas the system (an interacting assembly of varying complexity) is the means by which sculpture gradually departs from its object state and assumes some measure of lifelike activity." 25 By diminishing the distinction between art and life through systems theory, Burnham's perspective was a directed response and resistance to Michael Fried's criticism of the theatricality of minimalist art. ${ }^{26}$

Burnham's approach to systems in art is centered on the felt but unseen entities of art objects: "[t]he specific function of modern didactic art has been to show that art does not reside in material entities but in relations between people and the components of their environment." 27 Burnham, after Bertalanffy, suggests an approach to art that moves away from a focus on the object and towards art as a component within the larger system of society. In doing so, he abandons an inclination towards media specificity because his systems are defined by a "conceptual focus rather than material limits." 28 Burnham also privileges "systems esthetics" over the term "conceptual art," in order to highlight the technological expansion and emerging interdisciplinary nature of art in the 1960s, which for Burnham, Fried had undermined. ${ }^{29}$

Similarly to Frank Popper's appropriation of demateriality in participatory art, Burnham's systems theory is an articulation of the relationships among viewers, and between viewers and the art. $^{30}$ Some of these relationships are engaged through real-time interactions, however, Burnham also specifies that his take on systems theory can be applied to more

\footnotetext{
${ }^{21}$ Burnham, "Systems Esthetics," 17.

22 Ludwig von Bertalanffy, Robots, Men and Minds (New York: G. Braziller, 1967), 69.

${ }^{23}$ Burnham, "Systems Esthetics," 16. the Animal and the Machine (Cambridge, Massachusetts: The MIT Press, 1961).

${ }^{25}$ Burnham, Beyond Modern Sculpture, 10.

${ }^{26}$ Burnham, "Systems Esthetics," 17.

${ }^{27}$ Ibid., 16.

${ }^{28}$ Ibid., 17.

${ }^{29}$ Ibid., 17.

${ }^{30}$ Frank Popper, Art, Action and Participation (London: Studio Vista, 1975), 1-12.
}

${ }^{24}$ Lucy Lippard, Six Years: The Dematerialization of the Art Object from 1966-1972, $2^{\text {nd }}$ ed. (Berkeley: University of California Press, 1997/1993); Norbert Wiener, Cybernetics: Or Control and Communication in 
than the time-based, ephemeral staged environments and happenings. He argued that systems aesthetics "deals in a revolutionary fashion with the larger problem of boundary concepts. In systems perspective there are no contrived confines such as the theater proscenium or picture frame. Conceptual focus rather than material limits define the systems. ${ }^{\prime 11}$ Because of this post-formalist approach, systems aesthetics is an expansive and non-representational approach to art that has the potential to be applied to interpretations of art across a variety of practices.

As a quintessential exploration of systems theory in art, Burnham's argument drew upon German artist Hans Haacke's recent physiological and biological installations that involved studies of ecological and biological movement, such as Sky Line (1967), a project involving hundreds of helium-filled balloons connected together and cast out into the sky from Central Park. Another work, Photo-Electric Viewer Programmed Coordinate System (1968), involved a series of photoelectric sensors installed in the gallery walls with infrared beams fitted above at eye level. When viewers entered the space, the light bulbs became active, and lit up in correspondence to the movement of each viewer, while also performing random patterns of light choreography. As Haacke describes:

A 'sculpture' that physically reacts to its environment is no longer to be regarded as an object. The range of outside factors affecting it, as well as its own radius of action, reach beyond the space it materially occupies. It thus merges with the environment in a relationship that is better understood as a 'system' of interdependent processes ... A system is not imagined, it is real. ${ }^{32}$

However, for Burnham, Haacke's work signifies a shift in technological art that moves away from modern industrial kinesis and towards increasingly intelligent systems, a tendency that Burnham predicted to be an inevitable outcome for sculpture after modernity. ${ }^{33}$ Systems theory is used by Burnham as a key catalyst to regard kinetic art as an antiquated technological art that falls short from the emerging tendencies of conceptual, cybernetic and robotic art critiques and responds to the emerging technological age. ${ }^{34}$

To make this explicit, Burnham also drew from a range of artists working alongside Haacke to demonstrate that there was an emerging systems aesthetic in conceptual art in the 1960s. This included Dan Flavin's fluorescent installations, and the minimalist sculptural works by Robert Morris, Les Levine, and Donald Judd. In many cases, Burnham draws from systems and cybernetic theory to deconstruct the works. Within the discourse of "Systems Esthetics," Judd is compared to a computer programmer, while Carl Andre is described as having created assemblages of "modular forms." ${ }^{35}$ According to Burhnam, these artists revealed an ongoing "technological endeavor" in an attempt to intersect the relationships between conceptual and technological experimentations in art. ${ }^{36}$

Despite mention of Flavin, Morris, Levine, and Judd, Haacke's artwork was central to Burnham's understanding of systems-based art. This was admitted by Burnham, who stated: "[a]s a close friend of Hans Haacke since 1962, I observed how the idea of allowing his 'systems' to take root in the real world began to fascinate him, more and more, almost to a

\footnotetext{
${ }^{31}$ Burnham, "Systems Esthetics," 17.

32 Hans Haacke, Hans Haacke exh. cat. (New York: Howard Wise Gallery, 1968) unpaginated.

${ }^{33}$ Burnham, Beyond Modern Sculpture, 1-16.

${ }^{34}$ Ibid., 218-220.

${ }^{35}$ Ibid., 18 and 20.

${ }^{36}$ Ibid., 17 and 24.
} 
point of obsession. ${ }^{\prime \prime 3}$ Haacke reciprocated with equal appreciation by acknowledging that Burnham had introduced him to systems analysis, and was among the first to apply general systems theory to visual art. ${ }^{38}$

Although Burnham's approach to systems theory is unique, it echoed Norbert Wiener's approach to cybernetics. ${ }^{39}$ Through Wiener, systems theory became a way for negotiating the dematerialized work of art in computer, electronic and media art practices, by offering metaphors of software and hardware to describe the relationship between the concept and object in a work of art. The popularity of systems theory emerged concurrently with a number of complementary emerging theories in art theory and criticism. Like systems theory, the dematerialized post-object aesthetics that were popularized by conceptual artists in the 1960s concentrated on the construction and organisation of concepts. For George Dickie, this created a trend for emphsizing the way in which objects were organised and classified, rather than deconstructing the form of their physical properties. ${ }^{40}$ Like Dickie, Arthur Danto has likened the art world of the 1960 s to an entire regulated system. The nature in which artists referred to art historical tendencies to inform their practice, and their emphasis on the conceptual properties of a work of art, contributed to Danto's description of the art world as a "style matrix" that is built and organised by artists and institutions. ${ }^{41}$ Danto's systematic approach to art theory, history, and criticism offered an approach to art that was determined not by form or expression but a classification and differentiation of ontological and conceptual objects. Similarly, Burnham used systems theory to consider art as something that is built from a matrix of components that were organised by artists and institutions, rather than approaching a work of art as an autonomous object from which meaning can be drawn. This view focuses on the communicative relations that exist among the work, its viewers and the historical context. ${ }^{42}$

Norbert Wiener's theory of cybernetics also emphasized the connections among variables in technological information networks. For Wiener, the "second industrial revolution," which was propelled by the domestication of computing technologies, placed an emphasis on the input and feedback of information systems. Like systems and post-object aesthetics, Wiener related the information systems of computing technology as guided by processes, rather than objects, or as Ross Ashby has said, cybernetic theory emphasizes "not things, but ways of behaving." 43 As Charlie Gere has stated, Wiener's cybernetic theory was a rubric for approaching "biological, mechanic, and social processes across a number of

\footnotetext{
37 Jeanne Siegel, "An Interview with Hans Haacke," Arts Magazine, 46 (1971): 18.

${ }^{38}$ Hans Haacke, "Untitled Statement," in Hans Haacke, ed. John Bird, Walter Grasskamp, Molly Nesbit (London: Phaidon, 2004), 102.

${ }^{39}$ For account of Cybernetics, see Norbert Wiener, The Human Use of Human Beings: Cybernetics and Society (New York: Eyre and Spottiswoode, 1950); Norbert Wiener, Cybernetics: or, Control and Communication in the Animal and the Machine (Cambridge: Massachusetts, 1948).

${ }^{40}$ George Dickie, Art and the Aesthetic: An Institutional Analysis (Ithica: Cornell University Press, 1974).

${ }^{41}$ Arthur Danto, "The Artworld," The Journal of Philosophy, 61 (1964): 571-584. See also, Lawrence Alloway, "Network: The Art World Described as a System," in Network: Art and the Complex Present (Ann Arbor, Michigan: UMI Research Press, 1984).

42 Pamela Lee, Chronophobia: On Time in the Art of the 1960s (Cambridge Massachusetts: The MIT Press, 2004), 69. Niklas Luhmann has since reflected that, for many, art has become regarded as a social subsystem for society. See Niklas Luhmann, Art as a Social System (Stanford, California: Stanford University Press, 2000).

${ }^{43}$ Richard Ashby, An Introduction to Cybernetics (London: Chapman Hall, 1957), 1.
} 
disciplines outside the sciences, including art." ${ }^{44}$ Although Wiener and Ashby were reflecting on information systems in the decades prior to the 1960s, both cybernetic and systems theory intersected on multiple occasions in the latter decade. A prominent example was Burnham's "Sculpture as System" in Beyond Modern Sculpture, which will be addressed later in this paper. First, however, Burnham's critique of kineticism in art needs to be addressed.

\section{A Turbulent Relationship with Kineticism}

A problem with constructing a system, even one that is thought of as being open, ${ }^{45}$ is that there are always outliers to it. ${ }^{46}$ The exclusion of the study and orchestration of actual movement in art from contemporary criticism renders kinetic artists obsolete, and does not enable them to be considered contemporary. However, despite Burnham's de-emphasis of kinesis in art in "System Esthetics" and Beyond Modern Sculpture, systems theory is a key concern for artistis utilising kinesis in their work. For Haacke, actual movement in art has been used as an effective tool for rendering visible the unseen relationships among variables. This means that movement is not necessarily used in a formalist sense by exploring the rhythms of movement on a purely visual basis, but can be a means for presenting how relations between components move within systems.

Burnham's view on the emerging experiments with art and technology was also turbulent. A few short years after to the publication of "System Esthetics," Burnham wrote damning reviews on the collaboration between artists and engineers in exhibitions such as Los Angeles County Museum of Art's (LACMA) Art and Technology (1971). ${ }^{47}$ In a review for the exhibition published in Artforum Burnham wrote: "[i]f presented five years ago, A\&T would have been difficult to refute as an important event, posing some hard questions about the future of art. Given the effects of a Republican recession . . . few people are going to be seduced by three months of industry-sponsored art-no matter how laudable the initial motivation."48 Burnham's frustrations with collectives such as Experiments in Art and Technology (E.A.T), the exhibition Cybernetic Serendipity at the Institute of Contemporary Arts in London (1968), the department at the Massachusetts Institute of Technology, the Center for Advanced Visual Studies, and his own exhibition, Software, at the Jewish Museum in New York (1969) are detailed in his essay "Art and Technology: The Panacea that Failed." ${ }^{49}$ Burnham criticized the above exhibitions and organizations for being run by elitists with compromised funding from corporate sponsors and inadequate financial support from artistic and educational institutions. ${ }^{50}$ Burnham also criticised these institutions and the artists in the exhibitions for showing an overall technological incompetence and for failing to showcase emerging technologies in art. ${ }^{51}$ For Burnham, these setbacks were the reasons why

\footnotetext{
${ }^{44}$ Charlie Gere, Digital Culture (London: Reaktion Books, 2002), 52.

45 The definition of open system most notably refers to Umberto Eco's The Open Work. See Umberto Eco, The Open Work (Cambridge, Massachusetts: Harvard University Press, 1989). Eco also argues for a relationship between kinesis in art as a metaphor for open systems.

${ }^{46}$ Lee, Chronophobia, 243-246.

47 Jack Burnham, "The Panacea that Failed" in The Myths of Information; Technology and Postindustrial Culture, ed. Kathleen Woodward (London: Routledge, 1980), 210.

${ }^{48}$ Ibid., 210.

49 Ibid., 200-215.

${ }^{50}$ Ibid., 200-202.
} 
artists were so far unable to create "socially acceptable art" that utilized the latest emerging technologies, because artists demonstrated an "esthetic incompetency," as well as a lack of institutional and corporate support from sponsors. ${ }^{52}$

Burnham's criticisms of those working between science and technology within contemporary art were often directed at artists experimenting with kinesis. The popularity of kinetic art in the 1960 s became, for Burnham, a key reason why technological art was not being interpreted through general systems theory. In his words:

By the fact that most systems move or are in some way dynamic, kinetic art should be one of the more radical alternatives to the prevailing formalist esthetic. Yet this has hardly been the case. The best publicised kinetic sculpture is mainly a modification of static formalist sculpture composition. In most instances these have only the added bonus of motion, as in the case of Tinguely, Calder, Bury, and Rickey ... All too often gallery kinetic art has trivialized the more graspable aspect of motion: this is motion internalized and experienced kinesthetically. ${ }^{53}$

For Burnham, mechanical kinesis was too closely connected with formalist tendencies, which resulted in a continued desire to create motions purely from physical systems. ${ }^{54}$

As a former lumia and kinetic artist, Burnham's critique is largely cast by his disappointment with artists working with kinesis for resisting the emerging possibilities for incorporating technology into art at the time, such as robotic, cybernetic and virtual art. As he explained, "[t]he important thing is that the Kineticist is trying to make himself relevant in a world which is continually being recreated." ${ }^{25}$ Burnham's dissatisfaction with electromechanical sculpture was situated at the unrealized potential to assert kinesis within the emerging postmodern perspectives, ${ }^{56}$ and to re-engage with society as a dominant form of technological media art. $^{57}$

Despite Burnham's adamant exclusion of kineticism from systems aesthetics, in the same year Burnham published "Systems Esthetics" in Artforum, the director of Kineticism Press and curator of Kineticism: Systems Sculpture in Environmental Situations, Willoughby Sharp referred to kinetic artists as the forerunners of systems aesthetics. Sharp said that systems:

[A]re defined by their energy input . . . They are a cohesive collection of components relating to a single set of systems equations. These systems deal with facts about our physical reality... One of the major functions of these sculptural systems is to plug us into the actual forces that configure contemporary reality. ${ }^{58}$

\footnotetext{
${ }^{51}$ Burnham, "The Panacea that Failed," 211-215.

52 Ibid., 200, 211, and 212. Burnham goes on to explain that this is a "fundamental explanation" as to why he was disappointed by the efforts to explore technological solutions to visual art.

53 Burnham, "Systems Esthetics," 22.

${ }^{54}$ Burnham, Beyond Modern Sculpture, 220.

${ }^{55}$ Ibid., 284

${ }^{56}$ Ibid., 284

${ }^{57}$ Burnham, "Systems Esthetics," 22.

${ }^{58}$ Sharp, Air Art, 10.
} 
For Sharp, kinetic art not only performs the rhythms of movement and energy that flow through daily life but also acts as manifestations for how reality is perceived and framed by society. Sharp frames kinetic sculptural systems as a truly avant-garde practice that breaks down the boundaries between art and life: "[p]ainting and static sculpture are obsolete. They no longer relate to reality. They are anachronisms because they are irrelevant to our contemporary technological situation. It's idiotic and immoral to make such objects as art now. ${ }^{\prime \prime 5}$ Therefore, for Sharp, whether kinetic art is made from mechanical, biological, pneumatic or electronic media, it has the capability to perform visual manifestations of life as a series of systems.

Despite Burnham's disappointment in technological experiments in art during the $1960 \mathrm{~s}$ and 1970s, it cannot be ignored that a number of works by kinetic artists also strongly influenced his perspectives on the use of general systems theory in art. Among these are works by Len Lye, Otto Piene and Robert Breer's floats, and Group de Recherches d'Art Visue (GRAV) (a kinetic art collective that included Julio le Parc, François Morellet and Yvaral), ${ }^{60}$ although he did not focus on their use of actual movement. While Burnham argued that artists working with new technological media at the time were the forerunners of systems theory in art, and were developing new ways for visualizing and conceptualizing a systems approach to art in real-time, Burnham did not include kineticism in the frontline. ${ }^{61}$

Burnham's criticism of kineticism is also addressed explicitly in Beyond Modern Sculpture. He devotes an entire chapter to his argument that artists working with kinesis are inevitably unrequited by their aims because they failed to focus on new technological media. ${ }^{62}$ Burnham's intentions for systems theory in art was a way of understanding the emerging rubric of contemporary art in an increasingly technological society and also that art as a system would become the dominant framework for creating, experiencing, and distributing art in the future. ${ }^{63}$ This claim was explicit in his lecture at the Guggenheim museum in 1969, "The Aesthetics of Intelligent Systems," when he said:

Although the art of the future could take any one of a number of directions, it seems to me that, with the steady evolution of information processing techniques in our society, an increasing amount of thought will be given to the aesthetic relationship between ourselves and our computer environments-whether or not this relationship falls into the scope of fine arts. ${ }^{64}$

Using Haacke as an example, Burnham considered information processes as an effective way for communicating systems theory in art, to the point that "real-time information processing mode [was] rapidly becoming the routine style of handling information." 65 Burnham continues: "[w] hat a few artists are beginning to give the public is real-time information, information with no hardware value, but with software significance for effecting awareness of events in the present. ${ }^{\prime 66}$ This connection between concept as software and

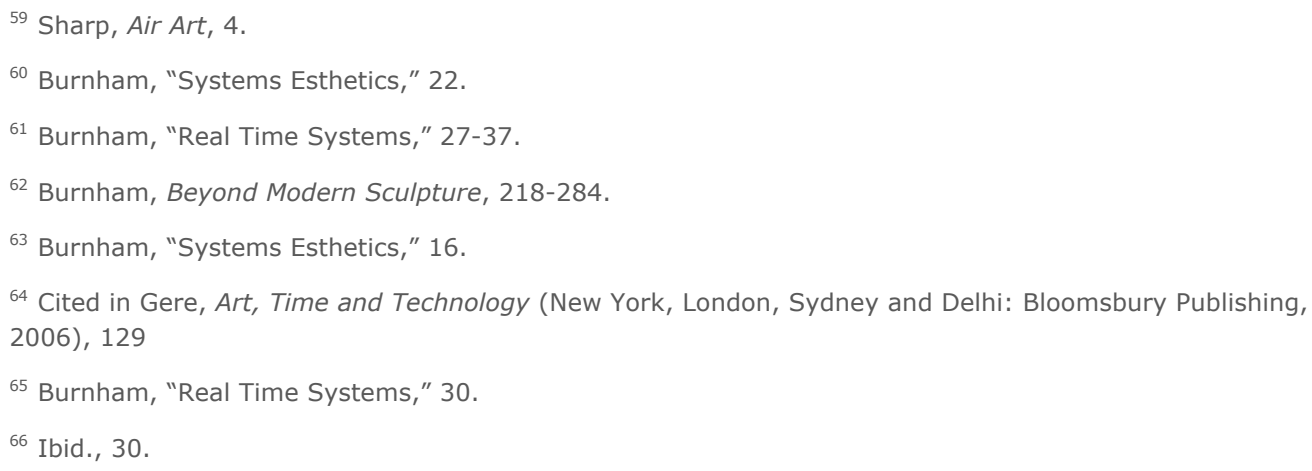


material as hardware contributes to a metaphor that compares art to processing systems and excludes an interpretation and discussion of the way these systems move.

\section{Hans Haacke's Kinetic Systems}

Burnham's approach to systems theory in art developed with, and alongside, Germanborn artist Hans Haacke's. The artist's interest in incorporating environmental systems in his art is used as one of Burnham's earlier examples of "systems esthetics" at play. According to Brunham, Hans Haacke's work highlights a significant shift in art that moves from technological art towards the orchestrations of cybernetic sytems. ${ }^{67}$

Burnham, however, fails to acknowledge that Haacke's early systems works performed kinetic dynamism to examine systems processes. ${ }^{68}$ Rather than discussing Haacke's use of movement to signify and perform information systems, Burnham instead describes Haacke's work with a vocabulary that spatializes the temporal movements of kinetic dynamism. Luke Skrebowski has argued that these early sculptures emphasized the movement of physiological, physical and biological processes and are central to Haacke's application of general systems theory that have persisted throughout his artistic career. ${ }^{69}$ In his analysis, Skrebowski problematizes Benjamin Buchloh's attempt to create a division between the artist's biological kinetic works and his more politically engaged art. Skrebowski argues that drawing such a distinction is a reductive binarism that patronizes the complexity of Haacke's early practice. ${ }^{70}$

Skewbowski's emphasis on Haacke's early sculptural works also problematizes Burnham's antipathy towards the intersection between kinetic dynamism and systems art. Burnham's argument overlooks Haacke's emphasis on ontological function and form as referrants for conceptual systems in his art in his attempt to exempt kinesis from postmodern interpretation. Rather, for Haacke, it was essential that the real-time processes and conceptual systems that were signified in his art, performed on a material level. As Haacke said, "I was primarily what you might call job-oriented. Even in the '60s, I wanted things to function, in a very literal, physical sense. ${ }^{171}$ It is these material kinetic systems that I would like to bring attention to, rather than Haacke's later socio-political systems art. This is because Haacke's emphasis on the movement of form as a referent for material and conceptual systems can also be used to problematize Burnham's regard for kineticism.

For instance, early installations such as Haacke's, Blue Sail (1964-65), Condensation Cube (1963-65) and Sky Line (1967) have often been dismissed by Benjamin Buchloh as experiments in "positivistic scientivism" all too preoccupied with technological rather than

\footnotetext{
67 Jack Burnham, "Real Time Systems," Artforum 8, no. 1 (1969): 49-55.

${ }^{68}$ Benjamin Buchloh has also previously delineated two distinct phases in Haacke's artistic career: his early kinetic systems and exploration of political systems. See, Buchloh, "Hans Haacke: Memory and Instrumental Reason," Art in America 76 (1988): 203-241.

${ }^{69}$ Luke Skrebowski, "All Systems Go: Recovering Hack Burnham's 'Systems Aesthetics'" Tate Papers 5 (Spring, 2006), accessed online May 17, 2014, http://www.tate.org.uk/research/publications/tatepapers/all-systems-go-recovering-jack-burnhams-systems-aesthetics.

70 Luke Skrebowski, "All Systems Go: Recovering Hans Haacke's Systems Art," Grey Room, no. 30 (Winter, 2008): 77.

71 Yve-Alain Bois, Douglas Crimp and Rosalind Krauss "A Conversation with Hans Haacke," October 30 (1984): 47.
} 
conceptual experimentation. ${ }^{72}$ Contemporary art history usually presents Haacke's systems art by privileging such as MOMA Poll News (1969), Shapolsky et al. Manhattan Real Estate Holdings, a Real-Time Social System, as of May 1971 (1971), which are works that each collate and display data over the duration of the exhibition. Each work materializes the invisible systems that traverse the everyday, such as a constant influx of political news, the hierarchical structure of real estate in New York, or the demographics of attendees at Haacke's exhibitions.

Yet much of the systems art by Haacke in the 1960 s and early 1970 s was created with an emphasis on the unstable nature of material through durational kinetic installation. For example, Condensation Cube (1963-65), Ice Stick (1966), Ice Table (1967), and High Voltage Discharge Traveling (1968) are all sculptures in which Haacke prioritizes the movement of natural-process energy systems like condensation, precipitation, evaporation, and the expansion and contraction in temperature change. Haacke also explored the movement of evolution, reproduction, birth and death in such works as Grass Cube (1967), Live Airborne System, November 30, 1968 (1968), Grass Grows (1969), Chickens Hatching (1969), Transplanted Moss Supported in an Artificial Climate (1970), Bowery Seeds, (1970), Goat Feeding in Woods (1970), Directed Growth (1970-72) and Rhine Water Purification Plant (1972). As with Haacke's data-processing systems art addressed earlier, these works are "event containers" that render visible the unseen movements of natural elements in the gallery setting. ${ }^{73}$

Haacke was concerned with rendering visible the ordinarily invisible facets of motion and energy and collapsing the distinction between life and art by performing actual motions in life, including the life cycle, metabolism, and the transfer of energy. Take for instance, Haacke's Chickens Hatching (1969), an installation that consists of fertilized chicken eggs, incubators, a lamp and a thermostat, which is both an exploration of kinetic movement and biological systems in art. For Burnham, Chickens Hatching presents "information [that] is derived from the normal activities of animals, in their environments. ${ }^{\prime 74}$ This is an example of "real-time information, information with no hardware value, but with software significance for effecting awareness of events in the present." ${ }^{175}$ While there is little specific hardware value to the installation in that time and place, the actual movements and behaviors of the chickens are the material processes, which perform the conceptual systems within the work.

It is important to note that these 1960 s and early 1970 s kinetic systems works were created at precisely the same time that Haacke was creating works that processed the information of social and political systems. Haacke's early artistic career did not move away from kinetic dynamism and towards systems art in a clean transition. Rather, kineticism was used early on to perform and experiment with biological and technological transformation of energy. This understanding renews a connection between kinetic and conceptual art and, as I have suggested, also problematizes Burnham's regard for kineticism as a practice that is inherently connected to the modern industrial revolution.

To quote Haacke, these works "make something which experiences, reacts to its environment, changes, is non-stable . . something which the 'spectator' handles, with which

\footnotetext{
72 Buchloh, "Hans Haacke: Memory and Instrumental Reason," 212.

${ }^{73}$ Walter Grasskamp, "Real Time: The Work of Hans Haacke" in Hans Haacke (New York and London: Phaidon, 2004), 36.

${ }^{74}$ Burnham, "Real Time Systems," 30.

75 Ibid., 28.
} 
he plays and thus animates .. . something which lived in time and makes the 'spectator' experience time. ${ }^{176}$ Haacke turns to a Bergsonian stance on the perception of duration, as a means of experiencing time, while concentrating on duration as a process of constant change. As time-pieces, Haacke therefore presents constructions of "natural" time in the sterile environments of artistic institutions, to present society in an age of technological expansion. Although there were moments when Haacke resisted the term "kinetic" to describe his works, the use of movement within many of his works during the 1960s was a focal aspect to his practice. ${ }^{77}$ For Haacke, movement is used to "merge with the environment in a relationship that is better understood as a 'system' of interdependent processes." ${ }^{78}$ To isolate the movement of a body of water into a perspex container works exactly to demonstrate that movement, even when it is enclosed, refers to and affects other movements (in this case the movements of Haacke's spectators interacting with the piece).

Haacke's Blue Sail (1964-65) is a simple movement study consisting of a sheet of blue chiffon, approximately 3.4 metres long and 3.2 metres wide, suspended horizontally in the air from the ceiling, and weighed down with fishing weights. Underneath the blue sail stands a small domestic fan pointed up towards the sail and panning across it. The sail is porous enough to form the shape of the wind created by the fan without entirely billowing and rising upward. The movement of the fan is made visible by the sail; it creates a wave that hovers in constant equilibrium. Blue Sail is one of Haacke's closed environmental "sculptural" systems works from the early 1960 s. $^{79}$ His focus on creating sculptures that produce their own weather systems, like other participatory art at the time, highlighted what Fried would call the duration of its objecthood. Blue Sail presents a movement that is perpetual and independent of viewers. The chiffon moves in front of its viewers, as well as when it is alone in the exhibition space. As Haacke explains:

A 'sculpture' that physically reacts to its environment is no longer to be regarded as an object. The range of outside factors affecting it, as well as its own radius of action, reach beyond the space it materially occupies. It thus merges with the environment in a relationship that is better understood as a 'system' of interdependent processes. These processes evolve without the viewer's empathy. He becomes a witness. A system is not imagined, it is real. ${ }^{80}$

Movement and time are important elements of Haacke's exploration of systems theory in art. Works like Blue Sail alter and work within the interior climate of the gallery space and function in time. In this way, motion is orchestrated to resist a modern definition of art as autonomous, finite and dependent on its crafted form. ${ }^{81}$ The components of Blue Sail each "physically communicate to one another." ${ }^{182}$ That is, the movement of one object (a fan)

\footnotetext{
${ }^{76}$ Hans Haacke, quoted in Obra Social: Hans Haacke. Barcelona: Fundación Antoni Tápies, 1995. Exhibition Catalogue, 49.

77 Caroline Jones, Hans Haacke 1967 (Cambridge: Massachusetts, MIT List Visual Arts Center, 2011), 9.

${ }^{78}$ Hans Haacke, quoted in Burnham "Systems Esthetics," 35.

79 Haacke's Rain Tower (1962) is a clear acrylic container that is divided into sections. Each section is perforated enough to enable water to pass through each division in trickles. When turned upside down, the water rains down to the bottom, "turning the grid from a visual into an operative structure." See Grasskamp, Real Time: The Work of Hans Haacke, 36.

${ }^{80}$ Burnham, "Systems Esthetics," 22.

${ }^{81}$ Walter Grasskamp, "Real Time: The Work of Hans Haacke" in Hans Haacke, eds. by Walter Grasskamp, Jon Bird, Molly Nesbit (London, Phaidon, 2004), 38.

82 Peter Mechsler, "Hans Haacke to Exhibit Kinetic Art," The Tech, October 17, 1967, 5, quoted in Caroline A. Jones, Hans Haacke 1967 (Cambridge, MA: MIT List Visual Arts Center, 2011), 9.
} 
causes an effect of movement to another (the sail), which also interacts with and is affected by the space and the viewers within it. The unstable or sensitive relationship that Blue Sail has with its environment emphasizes movement as an unfolding process that is not contained but open to its environment. It is a work that, like many of Haacke's early systems, "evolve[s] in time and [is] affected by time," rather than the phenomenological "shifting experience of the viewer." 84

Haacke created Blue Sail in order to bring the "spectator's" attention to the experience of time. ${ }^{85}$ The sculpture's movement is independent of its viewers; it moves in time and also affects time and performs Haacke's attempt to emphasize the transformation and process of energy movement systems. It is important that works such as Blue Sail and Photoelectric Viewer-Controlled Coordinate System perform Haacke's approach to systems theory rather than create a database or visualization of them, unlike socio-political systems such as those written about in News, MOMA Poll and Gallery-goers' Birthplace and Residence Profile. Providing a visualization of these systems would create an abstraction that distorts the unfolding nature of temporality. Kinesis is, therefore, a central tool for illuminating and performing the specific temporal arrangements in Haacke's systems art.

\section{Conclusion}

Burnham dismisses kineticism in "Systems Esthetics," "Real Time Systems," and Beyond Modern Sculpture. The influence of Burnham's scholarship on systems theory in art consequently has contributed to the "flagrant dearth" of critical and historical discussions of kineticism today. ${ }^{86}$ In these publications, Burnham argued that art in the late 1960s was increasingly moving away from an orientation of objects and towards a systems-based approach to creating and consuming art. The consequence, as Burnham has argued, positions kinetic artists as unrequited in their aims to contribute a popular technological artistic practice. ${ }^{87}$ The popularity and influence of Burnham's argument in contemporary media art history has contributed to an understanding of kinetic sculpture as a practice solely associated with the industrial machine aesthetic and modern avant-garde movements.

I have argued that Burnham's interpretation of kineticism misdirects Haacke's early sculptural systems art as early information-processing systems rather than experiments of movement systems. Contrary to Burnham, I argue that a sensitivity for, and discussion of, the actual kinetic movement in Haacke's works is a central aspect of the artist's understanding of systems aesthetics in art. While Burnham's antipathy towards kineticism separated kinesis from the emerging systems aesthetics in art, artists such as Haacke explicitly emphasized the importance of movement and form to connect media with specific conceptual messages. Haacke created works that were ontologically unstable in order to highlight the unfolding entropic nature within systems theory. Rather than a deference to actual movement, Haacke used motion to highlight it as a tool that is both material and immaterial, as well as actual and virtual.

\footnotetext{
${ }^{83}$ Peter Mechsler, "Hans Haacke to Exhibit Kinetic Art," 9.

${ }^{84}$ Ibid.

${ }^{85}$ Haacke, quoted in Obra Social: Hans Haacke, 49.

${ }^{86}$ Pierre, "Instability: The Visual/Bodily Perception of Space in Kinetic Environments," 91.

${ }^{87}$ Burnham, Beyond Modern Sculpture, 218-284.
} 


\section{(cc) EY-NG-ND}

This work is licensed under a Creative Commons Attribution-Noncommercial-No Derivative Works 3.0 United States License.

\section{ULLIS D-Sont}

This journal is operated by the University Library System of the University of Pittsburgh as part of its D-Scribe Digital Publishing Program, and is co-sponsored by the University of Pittsburgh Press. 